ORCID: 0000-0001-7883-6244

Uniwersytet Kazimierza Wielkiego w Bydgoszczy

ewafil@o2.p1

\title{
Badanie potencjału możliwości uczenia się dzieci - eksperyment nauczający
}

\section{Summary}

\section{The research on learning potential possibilities - teaching experiment}

Vygotsky's cultural-historical theory introduced new procedures in research methodology referring to the relationship between the zone of actual and proximal development. In the article I share my research experience resulting from an attempt to use in my research a teaching experiment in the understanding of Lev S. Vygotsky, the transition from the study of existing learning culture products and the diagnosis of the zone of actual development, the exploration of the child's learning potential, his/her susceptibility to teaching, estimation of the child's proximal development and cognitive readiness; from organizing a research situation in which the child independently solves the problem to exploring the potential of a child to solve a problem in cooperation with an adult, finally from examining both the child and the context to the study of the child in the context.

Keywords: zone of actual development (ZAD); zone of proximal development (ZPD), experimental-genetic method, teaching experiment, Vygotsky's theory-method, contextual method, developmental tasks

Słowa kluczowe: strefa aktualnego rozwoju, strefa najbliższego rozwoju, metoda mikrogenetyczna, eksperyment nauczający, teorio-metoda Wygotskiego, potencjał możliwości uczenia, metoda kontekstualna, zadania rozwojowe

\section{Wprowadzenie}

Istotę dzieciństwa stanowi zmiana. Jej badanie, analiza, opis i interpretacja zjawiska (przebiegu rozwoju) stanowi jedno z najtrudniejszych problemów badawczych i jest niewątpliwie wyzwaniem dla badacza projektującego strategię badań (Brzezińska 2000: 142). W ostatnich latach obserwujemy zmiany, jakie dokonały się w obrębie badań rozwoju i uczenia się dzieci. Nastąpił zwrot w kierunku badań uwzględniających społeczny kontekst uczenia. Zaobserwowano nową falę badań nad „umysłami” innych z uwzględnieniem dziecięcej perspektywy w procesie przyswajania wiedzy. W studiach nad dziecięcym poznawaniem, uczeniem się i rozwojem widoczne jest przesunięcie i zainteresowanie ukierunkowane na rozumienie, jak dziecko myśli, w jaki sposób dochodzi do własnych przekonań, jak struk- 
turyzuje własne uczenie się, domyślanie, myślenie. W badaniach tych dziecku przyznaje się status podmiotu poznającego, uczącego się, konstruującego własny model świata. Analizowane w ten sposób intuicje dziecka pozwalają rekonstruować korzenie, drogi budowania wiedzy i układu uczenia się (Bruner 2006). J.S. Bruner, pisząc o zmianie, jaka dokonała się w zakresie poznawania i uczenia się dzieci, wskazuje cztery wyłaniające się kierunki badań. Są to: (1) badania nad intersubiektywnością ukierunkowane na rozumienie tego, w jaki sposób dzieci rozwijają zdolność „czytania innych umysłów”, (2) badania „teorii umysłu”, czyli badania nad tym, ,w jaki sposób dzieci przyswajają sobie przekonania na temat tego, jak inni dochodzą do rozmaitych stanów umysłowych"; (3) studia nad metapoznaniem ukierunkowane na rekonstruowanie tego, co dzieci myślą na temat uczenia, zapamiętywania oraz procesów myślowych oraz (4) badania nad kooperatywnym uczeniem, zorientowane na rozumienie, jak dzieci zdobywają i przetwarzają wiedzę w dyskusji (Bruner 2006). W polskim dyskursie naukowym, w realizowanych projektach badawczych, obecne są te nurty i podejścia. Przykładem takich projektów są prace K. Stemplewskiej-Żakowicz (2004), M. Wiśniewskiej-Kin (2009) czy D. Klus-Stańskiej (2002).

Oprócz wskazanych przez J.S. Brunera kierunków wyłonił się nurt badań, w którym analizuje się jednostkę w relacji wzajemnej i zwrotnej względem otoczenia, w którym jednostka żyje i rozwija się. Jest to podejście kontekstualne do badań. W artykule dzielę się doświadczeniem badawczym wynikającym z próby zastosowania w badaniach metody eksperymentu nauczającego (formatywnego) w rozumieniu Lwa S. Wygotskiego, przejścia od badania zastanych „produktów” kultury uczenia się i diagnozy strefy aktualnego rozwoju do badania potencjału możliwości uczenia się dziecka i diagnozy jego strefy najbliższego rozwoju; od organizowania sytuacji badawczej, w której dziecko samodzielnie rozwiązuje problem do badania potencjału możliwości rozwiązania problemu przez dziecko we współpracy z dorosłym, wreszcie od badania dziecka i kontekstu do badania dziecka w kontekście.

\section{Badanie zmiany rozwojowej - podejście kontekstualne}

W psychologii można wyróżnić zasadniczo dwa odmienne podejścia do analizy zjawiska rozwoju i zmiany rozwojowej, jest to podejście mechanistyczne i organizmiczne. Każde z nich zakłada inną wizję natury człowieka, jego funkcjonowania oraz relacji wobec otoczenia (por. kryteria wyłaniania modeli przebiegu zmiany rozwojowej; Brzezińska 2000: 137-142). $\mathrm{Z}$ podejścia organizmicznego, które zakłada aktywność organizmu w formowaniu własnego doświadczenia, wyrosło podejście kontekstualne (szerzej Brzezińska 2000: 58-59). Podstawowym założeniem tego podejścia jest ujmowanie jednostki w relacji $\mathrm{z}$ otoczeniem i vice versa, stąd kluczowym pojęciem jest dynamiczna interakcja. Konsekwencją przyjęcia tego stanowiska jest uznanie, iż centralną rolę w wyjaśnianiu przebiegu i ocenie efektów rozwoju odgrywa zjawisko dopasowania się w czasie gotowości jednostki i gotowości kontekstu jej rozwoju (Brzezińska 2000: 59), tj. analizowania nie tyle dziecka i kontekstu, ale dziecka w kontekście. Właściwości (atrybuty) jednostki mają znaczenie dla jej rozwoju wyłącznie w kreowanej społecznie sytuacji, w której wchodzi ona w aktywny, relacyjny kontakt z okre- 
ślonymi aspektami kontekstu rozwoju. Kontekstualny model rozwoju jednostki opracowany przez R.M. Lernera wyznacza swoistą ramę interpretacyjną, a wraz z nią inne procedury, strategie badań, inne reguły wnioskowania, określone założenia dla kreowania sytuacji badawczej. Badacz i osoba badana wchodzą w interakcję, która zwrotnie kształtuje ich zachowania. Podejście kontekstualne sprawia, że badacz poszukuje znacznie bardziej zróżnicowanego warsztatu; narzędzi badań, projektuje sesje badawcze, w konsekwencji buduje zróżnicowany i wielopoziomowy bogaty model uwarunkowań danego zjawiska (Brzezińska 2000: 161164). Szczególnym podejściem wyłaniającym się z modelu kontekstualnego jako podstawy planowania badań jest oryginalne podejście Lwa S. Wygotskiego i jego teorio-metoda.

\section{Podejście Lwa S. Wygotskiego do badania rozwoju i uczenia się}

Rozwój psychiki ludzkiej według Wygotskiego jest upośredniony (oposriedstwowannyj) materialnie (poprzez używanie narzędzi, produkcję dóbr materialnych) oraz społecznie (poprzez narzędzia i znaki będące wytworem kultury i przekazywane z pokolenia na pokolenie przez kulturę) (Wygotski 1971; 1989). W rozumieniu Wygotskiego rozwój jest osiągnięciem społecznym zarówno co do treści, jak i procesu jego przebiegu (zob. Wygotski 1971). Znamienna dla teorii Wygotskiego teza, iż wyższe funkcje umysłowe mają swoje źródło w społecznym działaniu i ogólne, genetyczne prawo rozwoju kulturowego mają konsekwencje metodologiczne, istotne dla ramy interpretacyjnej i badawczej:

[...] każda wyższa funkcja psychiczna pojawia się w rozwoju dziecka dwukrotnie: raz jako działalność zespołowa, społeczna czyli jako funkcja interpsychiczna, drugi raz jako działalność indywidualna, jako wewnętrzny sposób myślenia dziecka, jako funkcja intrapsychiczna (Wygotski 1971: 544).

Wygotski zwraca uwagę na ścisłe powiązanie i relację, jaka zachodzi pomiędzy społeczną a indywidualną organizacją zachowań:

[...] Poziom zdolności generalizacji u dziecka odpowiada dokładnie poziomowi rozwoju interakcji społecznej. Każdy nowy poziom zdolności generalizacji u dziecka oznacza nowy poziom możliwości interakcji społecznej (Wygotski 1971: 432).

Przedmiotem badania Wygotski uczynił zjawiska i procesy centralne w rozwoju człowieka. Jego zdaniem badacz powinien być zainteresowany procesem powstawania lub ustalania się wyższej formy rozwoju, a nie rezultatem końcowym, gotowym wynikiem (Wygotski 1971: 76). Badał to, co może zrobić już dziecko samodzielnie, ale przede wszystkim był zainteresowany badaniem tego, co dziecko może osiągnąć przy pomocy innych (Wygotski 1971; Shotter 1994). Podejście badawcze zaproponowane przez Wygotskiego jest związane z diagnozowaniem strefy najbliższego rozwoju dziecka i jest wyrazem dynamicznego podejścia do badania rozwoju umysłowego dziecka. Taka procedura badawcza zakłada celowe konstruowanie społecznej sytuacji opartej na inicjatywnej współpracy i interakcji pomiędzy 
badaczem a osobą badaną (por. Filipiak 2018). Kluczowe w tym podejściu pojęcia są aktywność kształtująca i instrukcja formatywna. W raporcie z badań rejestrującym przebieg interakcji pomiędzy dzieckiem a badaczem poddawana jest analizie m.in. ilość, częstotliwość, jakość wskazówek pozwalających dziecku na rozwiązanie zadania, współzmienność i dostrajanie zachowań partnerów interakcji (por. Filipiak, Lemańska 2015a,b). Przedmiotem zaproponowanej przez Wygotskiego eksperymentalno-genetycznej metody badań (eksperymentu mikrogenetycznego) jest analiza dynamiczna procesu powstawania i kształtowania się reakcji, rekonstrukcja momentu powstawania, kształtowania końcowej formy, odtworzenie dynamicznego obrazu całego procesu jej rozwoju (Wygotski 1971; Filipiak 2018).

Zadaniem badania genetycznego nie jest jednak thumaczenie powstawania nowych form zachowania aktem odkrywania, lecz przeciwnie, jego zadaniem jest pokazanie samych początków tego rozwoju, jego roli w zachowaniu się dziecka, jak również roli innych czynników determinujących jego przejawy i wpływy (Wygotski 1971: 114).

W tej procedurze badawczej znaczącą rolę pełni obserwacja i jej narzędzia. Metoda obserwacyjna i eksperymentalna pozostają ze sobą nie tylko w związku genetycznym, ale splatają się w jednolitym procesie badawczym (Smykowski 2017). Wygotski zwraca uwagę na istotną trudność analizy genetycznej, która

[...] polega właśnie na tym, aby za pomocą eksperymentalnych, sztucznie wywołanych procesów zachowania się zbadać, jak przebiega naturalny proces rozwojowy.[...] Zadaniem badania genetycznego jest zawsze przeniesienie schematu eksperymentalnego do realnego życia (Wygotski 1971: 113).

Badania eksperymentalne prowadzone w przestrzeni laboratorium pozwalają na odkrywanie jedynie abstrakcyjnych schematów rozwoju, porządku następstw czy reguł. Dopiero przeniesienie schematu eksperymentalnego do realnego życia i napełnienie go konkretną treścią pozyskaną drogą pozaeksperymentalną pozwoli badaczowi na nadawanie rzeczom sensu w praktyce, odkrycie i prześledzenie naturalnej historii znaku i mechanizmu jego rozwoju (Wygotski 1971: 113-115; Smykowski 2017). Stosując badania mikrogenetyczne, wykorzystujemy zapis wideo, rejestrujemy w ten sposób relacje, zachowania partnerów interakcji, analizujemy ich zachowania w społecznej sytuacji badawczej. Konsekwencją metodologiczną tego podejścia jest także poszukiwanie i zastosowanie narzędzi badawczych umożliwiających rejestrowanie przebiegu badań. Sesje badawcze są rejestrowane, aby potem móc poddać analizie zmienność sytuacji badawczej, jej dynamikę, zakres relacji i interakcji i w ten sposób uzyskać wiarygodne informacje o poziomie możliwości badanej osoby (Brzezińska 2000).

\section{Na czym polega specyfika eksperymentu nauczającego?}

W projektowanych badaniach według metodologii CHAT (Cultural-Historical Activity Theory) pojawiają się dwie kategorie charakteryzujące tę procedurę badawczą: metoda podwój- 
nej stymulacji (mikrogenetyczna) i eksperyment nauczający. Metoda podwójnej stymulacji (mikrogenetyczna) jest to metoda badawcza, w której ,jedna grupa bodźców pełni funkcję obiektu działalności osoby badanej, druga - znaków pozwalających zorganizować tę działalność" (Stachowski 2002: 30). Pierwsza grupa bodźców to są bodźce ukierunkowujące działania badanego (bodźce - cele), natomiast druga grupa bodźców to bodźce pomocnicze (bodźce - środki) (zob. Smykowski 2000: 142). Eksperyment nauczający jako metoda badania rozwoju psychicznego odwołuje się do odkrytej przez L.S. Wygotskiego relacji między strefą aktualnego i najbliższego rozwoju. Podstawową cechą eksperymentu nauczającego, jak zauważa Dawydow (za: Zak 1989: 41), nie jest ,[...] proste konstruowanie właściwości tych lub innych empirycznych form psychiki, a ich aktywne modelowanie, kształtowanie w specjalnych warunkach pozwalających wykryć ich istotę".

Taka procedura jest ukierunkowana na odkrycie potencjału uczenia i podatności dziecka na nauczanie. Umożliwia obserwowanie zmiany rozwojowej w codziennych praktykach, w rzeczywistych warunkach lub podobnych do nich, tworzy okazję obserwowania aktywnych form działalności i uczestnictwa badanego w rozwiązywaniu zadań i sposobów korzystania z pomocy interwencjonisty, umożliwia kontrolowanie jakości motywacji i zaangażowania badanego do wykonywania zadań, samokontrolę i samoregulację dziecka (Zak 1989; też: Stachowski 2002; Smykowski 2000; Filipiak 2018; Brown, Ferrara 1994). Sytuacja badawcza (składająca się zazwyczaj z kilku powiązanych sesji) jest swoistą sytuacją budowania układu uczenia się. Dziecko, uczestnicząc w badaniu, uczy się czegoś nowego, rozwiązując problemy (najpierw we współpracy z dorosłym, potem samodzielnie), używając narzędzi mentalnych, mediatorów (nie tylko ludzkich). Badacz, wchodząc celowo w interakcje z dzieckiem, wywiera wpływ przez swoje zachowanie, instrukcje formatywne na zachowanie (działalność, aktywność) dziecka. Rejestruje i zbiera dane, które pozwolą mu wyznaczyć szerokość strefy najbliższego rozwoju w badanym obszarze. Odnotowuje zarówno to, co dziecko jest w stanie wykonać samodzielnie, jak i to, w jaki sposób narzędzia są absorbowane, przyswajane przez dziecko. Rejestruje to, co (i w jaki sposób) może dziecko wykonać przy pomocy innych (Filipiak 2018; Filipiak, Lemańska-Lewandowska 2015a,b: 44; Brzezińska 2000; Brown, Ferrara 1994). Tak pomyślaną i zaplanowaną procedurę metodologiczną zastosowano w eksperymencie formatywnym w projekcie Nauczanie rozwijajace we wczesnej edukacji wedtug Lwa S. Wygotskiego (ACK) ukierunkowanym na monitorowanie rozwoju myślenia teoretycznego u dzieci w wieku 6-10 lat (por. Filipiak, Lemańska-Lewandowska 2015a).

\section{Strefa Aktualnego vs Strefa Najbliższego Rozwoju: diagnoza „produktu” vs diagnoza potencjału możliwości i podatności na nauczanie}

Stwierdzenie Wygotskiego, iż „nikt nie może kwestionować faktu, iż nauczanie należy jakoś uzgadniać z poziomem rozwoju dziecka" (1971: 540) ma swoje konsekwencje w jego dalszych ustaleniach: 
[...] niepodobna poprzestać na jednym określeniu poziomu rozwoju. Koniecznie trzeba ustalić przynajmniej dwa poziomy w rozwoju dziecka (podkreśl. Wygotskiego). Nie znając ich, nie potrafimy w żadnym konkretnym przypadku prawidłowo określić stosunku między poziomem rozwoju danego dziecka a jego możliwościami w nauce (Wygotski 1971: 540-541).

Stąd Wygotski wyodrębnia strefę aktualnego i najbliższego rozwoju. Strefa aktualnego rozwoju (SAR; zone of actual development; ZAD) ujawnia poziom kompetencji już osiągniętych przez dziecko. Obejmuje zakończone cykle rozwoju, operacje, działania, umiejętności, nawyki zinternalizowane, w zakresie których dziecko już osiągnęło pewne kompetencje, ale wciąż doskonali i wzbogaca ich jakość. Strefa najbliższego rozwoju (SNR; zone of proximal development; $Z P D)$ określa różnicę pomiędzy poziomem wykonania zadan dostępnych pod kierunkiem i przy pomocy dorosłych a poziomem wykonania zadań dostępnych w samodzielnym działaniu dziecka, rzeczywistym poziomem rozwojowym, w którym demonstruje ono samodzielne, niezależne wykonywanie zadań. Inaczej ujmując, można powiedzieć, że SNR określa różnicę pomiędzy kompetencją wspieraną z zewnątrz a kompetencją pozbawioną takiego wsparcia. (por. Wygotski 1989; Wood 2006: 90; Bodrova, Leong 2007: 40; Filipiak 2011: 16-17; Filipiak 2015 c; Brzezińska 2000: 137-142).

[...] istotną cechą nauczania jest to, iż tworzy ono strefę najbliższego rozwoju dziecka, czyli daje początek wielu wewnętrznym procesom rozwoju, rozwija i uruchamia te procesy, na razie dostępne dziecku tylko w sferze obcowania z otoczeniem i współpracy z kolegami, a potem, po przejściu rozwoju wewnętrznego, stające się wewnętrznym dorobkiem samego dziecka (Wygotski 1971e: 545).

Brown i Ferrara opisują strefę najbliższego rozwoju (SNR) jako „mapę obszaru gotowości dziecka do wykonania zadania, którą na niższym końcu ogranicza obecny poziom umiejętności, na wyższym poziom umiejętności, które dziecko może osiągnąć w najbardziej korzystnych warunkach" (1994: 37). Umiejętności i zachowania dziecka w SNR są dynamiczne i stale zmieniające się, co oznacza, że poziom wykonania wspieranego i poziom poczucia sprawstwa będzie się zmieniał wraz z rozwojem dziecka. Istnieje wiele konsekwencji oryginalnej koncepcji i teorii Wygotskiego SNR i rozróżnienia SAR i SNR. Między innymi są to konsekwencje i tropy metodologiczne związane z projektowaniem sytuacji badawczej, narzędzi diagnostycznych.

Celem badania ukierunkowanego na SAR jest zakres aktualizacji posiadanego przez dziecko doświadczenia. Najczęściej są to zadania testowe, które dziecko wykonuje samodzielnie rozwiązując problem. Inne możliwości tworzą procedury ukierunkowane na ocenę/diagnozę potencjału możliwości uczenia w SNR. Badacz zainteresowany jest diagnozą zakresu korzystania przez dziecko z nowego doświadczenia, wskazówek (Brown, Ferrara 1994; Brzezińska 2000; Smykowski 2017). Są to badania eksperymentalne, w których dziecku stawia się zadania otwarte, trudne, wymagające pomocy i wsparcia. W sesjach diagnostycznych realizowanych w Rosji, w Laboratorium Wygotskiego (w najdłuższym 
eksperymencie formatywnym zainicjowanym przez Elkonina i Dawidowa, który trwa od 1958 roku w Moskwie, w Szkole nr 91), mierzona jest skuteczność uczenia się w obszarze danego zadania. Szacując szerokość SNR, analizuje się, ile i jakich wskazówek potrzebuje dziecko do rozwiązania problemu 1., problemu 2., problemu 3. itd. Mierzy się także i monitoruje wielkość transferu i internalizacji procedur (Brown, Ferrara 1994). Diagnozowanie obszaru gotowości dziecka i szacowanie SNR wymaga szczegółowej analizy treściowej problemu i właściwego wyboru zadań stawianych dziecku, które pozwolą na uchwycenie relacji, śledzenie drogi konstruowania wiedzy, szczegółowej analizy możliwego transferu. Są to specyficzne zadania rozwojowo-dydaktyczne, zadania problemy ukierunkowane na pobudzanie operacji myślowych: porównywanie, analizę, syntezę, abstrahowanie, uogólnianie (por. Filipiak 2015c, 2018). W badaniach eksperymentalnych ukierunkowanych na monitorowanie myślenia teoretycznego u dzieci w wieku 6-10 lat realizowanych w projekcie Nauczanie rozwijajace we wczesnej edukacji wedtug Lwa S. Wygotskiego (ACK) zastosowano zróżnicowane autorskie typy zadań w opracowaniu E. Filipiak (2015c).

$\mathrm{W}$ toku prac przygotowujących do realizacji eksperymentu formatywnego opracowano 3 typy zadań umożliwiających dziecku przejście z obszaru SNR do SAR. Są to:

1. Zadania MOŻLIWOŚCI: „chcę, potrafię z Twoja pomocą”, w których działania dziecka są wspierane przez inne, bardziej kompetentne osoby. Dorosły buduje układ uczenia się, wzbogaca poszczególne etapy pracy dziecka wyjaśnianie. Istotne dla realizacji zadania są instrukcja formatywna i feedback.

2. Zadania KOMPETENCJE: ,wiem jak, spróbuję sam”, w których dziecko samo wspiera się w działaniu. Stanowią etap przejściowy pomiędzy działaniem realizowanym na podstawie wskazówek regulujących działanie, ale pochodzących od innych, a etapem internalizacji zadania.

3. Zadania POCZUCIE KOMPETENCJI: ,wiem jak, potrafię sam": uczeń osiąga samodzielność w wykonaniu zadania. Działanie dziecka jest samoregulowane, wiedza o wykonaniu zadania zostaje zinternalizowana.

Zadanie bazowe obejmujące sekwencję zadań szczegółowych (typu 1-2-3) pozwala na przesunięcie zadania z obszaru świadomości peryferycznej do centralnej, odkrycia i opanowania przez uczącego się ogólnego sposobu (zasady) podczas rozwiązywania zadań cząstkowych i wykonywania specyficznych czynności. Szczegółowa charakterystykę zadań zawarto w pracy Filipiak 2015c.

\section{Co wiemy o dzieciach i ich zdolnościach uczenia się na podstawie kreowania różnych sytuacji badawczych i zastosowania różnych narzędzi?}

W realizowanych projektach badawczych, ukierunkowanych na diagnozę zdolności uczenia się dzieci, przeprowadzono zarówno diagnozę strefy aktualnego rozwoju, jak również badania potencjału możliwości uczenia się dziecka, podatności na nauczanie, podjęto próbę szacowania strefy najbliższego rozwoju i gotowości poznawczej dziecka w obszarze myślenia teoretycznego. Działania badawcze były ukierunkowane zarówno na organizo- 
wanie sytuacji badawczej, w której dziecko samodzielnie rozwiązywało problem, jak również do badania potencjału możliwości rozwiązania problemu przez dziecko we współpracy z dorosłym, wreszcie od badania dziecka i kontekstu do badania dziecka w kontekście.

W latach 2006-2009 zrealizowano projekt MNiSW Nr 107037 31/38/75 Rozwój zdolności uczenia się uczniów szkoły podstawowej i gimnazjum (por. Filipiak 2009). Celem badań była diagnoza zdolności uczenia się uczniów szkoły podstawowej i gimnazjum. Badaniami objęto grupę 500 uczniów szkoły podstawowej i gimnazjum, przyjmując grupy wyodrębnione ze względu na wiek i płeć. Zdolności uczenia się uczniów scharakteryzowano za pomocą standaryzowanego testu SOI-La (Learning Abilities Test), poddając analizie 5 kategorii operacji: Poznawanie, Pamięć, Ocenianie, Wytwarzanie Konwergencyjne, Wytwarzanie Dywergencyjne oraz zdolności warunkujących skuteczne uczenie się: zdolność czytania, zdolności matematyczne, zdolności pisania, kreatywność. Na podstawie tych wyników wykreślono dla każdej z grup badanych (III, IV, VI szkoły podstawowej, klas I i III gimnazjum) profile zdolności oraz określono style uczenia (Filipiak 2009; Filipiak 2013; Filipiak 2015a; Filipiak 2015b). Poniżej zaprezentowano przykładowe profile zdolności uczenia się z dwóch grup badawczych wyznaczających granice etapów edukacji (koniec I i koniec III etapu edukacyjnego).

\begin{tabular}{|c|c|c|c|c|c|c|c|c|c|c|c|c|c|c|c|c|c|c|c|c|c|c|c|c|c|c|}
\hline \multirow{2}{*}{ ZDOLNOŚCI } & \multicolumn{9}{|c|}{ POZNAWANIE } & \multicolumn{6}{|c|}{ PAMIĘĆ } & \multicolumn{4}{|c|}{ OCENIANIE } & \multicolumn{4}{|c|}{$\begin{array}{c}\text { WYTWARZANIE } \\
\text { KONWERGENCYJNE }\end{array}$} & \multicolumn{3}{|c|}{$\begin{array}{l}\text { WYTWARZANIE } \\
\text { DYWERGENCYJNE }\end{array}$} \\
\hline & CFU & CFC & CFS & CFT & CSR & CSS & CMU & CMR & CMS & MFU & MSU-V & MSS-V & MSU- & MSS-A & MSI & EFU & EFC & ESC & ESS & NFU & NSS & NST & NSI & DFU & DMU & DSR \\
\hline Uzdolniony & 11 & 8 & 22 & 16 & 4 & 6 & 16 & 19 & 17 & 17 & 17 & 12 & 17 & 6 & 10 & 16 & 9 & 14 & 5 & 33 & 2 & 120 & 17 & 47 & 81 & 83 \\
\hline Wybitny & 10 & 7 & 17 & 13 & 3 & 6 & 13 & 17 & 15 & 16 & 16 & ב⿱ & 16 & 3 & 8 & 15 & 8 & 12 & 4 & 32 & 11 & 102 & 12 & 39 & 64 & 68 \\
\hline $\begin{array}{c}\text { Powyżej } \\
\text { przeciętnej }\end{array}$ & 8 & & 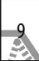 & 10 & 2 & 5 & 11 & 15 & 12 & 13 & 15 & 3 & 14 & $\underline{E}$ & 6 & & & & & 22 & 0 & 85 & 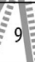 & 33 & 44 & 53 \\
\hline Przeciętny & 7 & 4 & 8 & $\frac{3}{3}$ & 2 & 4 & 10 & 13 & 10 & 12 & 14 & 0 & 12 & 0 & 5 & $\mathbf{1 2}$ & 7 & 列 & 2 & 21 & 0 & 74 & 7 & 29 & 36 & 42 \\
\hline $\begin{array}{c}\text { Poniżej } \\
\text { przeciętnej }\end{array}$ & 6 & 4 & 4 & 6 & 1 & 3 & 8 & 11 & 8 & $=10$ & 亲 & 0 & 11 & 0 & 4 & 10 & 6 & 8 & 2 & 18 & 0 & 62 & 6 & 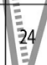 & $28^{\circ}$ & 30 \\
\hline Ograniczający & $5^{\circ}$ & 2 & 1 & 4 & 0 & 1 & 7 & 9 & 6 & 7 & 11 & 0 & $8=$ & 0 & 3 & 8 & 5 & 7 & 1 & 13 & 0 & 45 & 5 & $188^{\circ}$ & 19 & 23 \\
\hline Upośledzający & 2 & 1 & 0 & 2 & 0 & 0 & 5 & 8 & 4 & 4 & 8 & 0 & 5 & 0 & 2 & 6 & 4 & 4 & 0 & 10 & 0 & 25 & 3 & 11 & 11 & 17 \\
\hline
\end{tabular}

Rys. 1a. Profil zdolności uczenia się - klasa III szkoła podstawowa (linia ciągła - kobiety, linia przerywana - mężczyźni)

Źródło: E. Filipiak 2009: 59.

Profile te dostarczyły dużo informacji o zdolnościach uczenia się dzieci. Uwidoczniły przede wszystkim końcowy efekt uprzedniego uczenia się, produkty szkolnego uczenia się. Są statyczne. Nie dostarczają bezpośredniej informacji odnośnie do poziomu wykonania, do którego uczniowie byliby zdolni. Standaryzowana procedura testu SOI-LA (Meeker i in. 1985) wymagała takiego samego środowiska badania, nieudzielania dodatkowych instrukcji dziecku podczas samodzielnego wykonywania zadania przez dziecko niż te instrukcje, które zostały zawarte w teście. 


\begin{tabular}{|c|c|c|c|c|c|c|c|c|c|c|c|c|c|c|c|c|c|c|c|c|c|c|c|c|c|c|}
\hline \multirow{2}{*}{ ZDOLNOŚCI } & \multicolumn{9}{|c|}{ POZNAWANIE } & \multicolumn{6}{|c|}{ PAMIĘC } & \multicolumn{4}{|c|}{ OCENIANIE } & \multicolumn{4}{|c|}{$\begin{array}{c}\text { WYTWARZANIE } \\
\text { KONWERGENCYJNE }\end{array}$} & \multicolumn{3}{|c|}{$\begin{array}{l}\text { WYTWARZANIE } \\
\text { DYWERGENCYJNE }\end{array}$} \\
\hline & $\mathrm{CFU}$ & CFC & CFS & CFT & CSR & CSS & CMU & CMR & CMS & MFU & MSU-V & MSS-V & MSU-A & MSS-A & MSI & EFU & EFC & ESC & ESS & NFU & NSS & NST & NSI & DFU & DMU & DSR \\
\hline Uzdolniony & 14 & 9 & 26 & 21 & 8 & 8 & 23 & 24 & 21 & 21 & 18 & 18 & 18 & 15 & 15 & 23 & 14 & 26 & 8 & 33 & 8 & 172 & 21 & 38 & 102 & 99 \\
\hline Wybitny & 14 & 8 & 25 & 17 & 6 & 8 & 22 & 23 & 21 & 19 & 18 & 15 & 17 & 13 & 12 & 21 & 13 & 25 & 8 & 33 & 8 & 165 & 21 & 35 & 90 & 90 \\
\hline $\begin{array}{c}\text { Powyżej } \\
\text { przeciętnej }\end{array}$ & 13 & 8 & 25 & 14 & 5 & 7 & $2 \bar{E}$ & 22 & 20 & 16 & 17 & & 17 & 9 & 113 & 20 & 12 & 24 & 8 & 30 & 7 & 154 & 20 & 32 & 84 & 85 \\
\hline Przeciętny & 12 & 7 & 24 & 12 & 75 & 17 & 20 & 22 & 19 & & 17 & 13 & 16 & 7 & 9 & 19 & 11 & 21 & 7 & 129 & 6 & 142 & 20 & 28 & 73 & 80 \\
\hline $\begin{array}{c}\text { Poniżej } \\
\text { przeciętnej }\end{array}$ & 10 & 7 & 79 & 10 & 4 & 6 & 18 & 21 & 17 & & 15 & 12 & 5 & 5 & 8 & 17 & 10 & 18 & 6 & 22 & 5 & 125 & 17 & 23 & 61 & 55 \\
\hline Ograniczający & $9 !$ & 116 & 15 & 8 & 3 & 6 & 17 & 20 & 115 & 10 & 15 & 11 & 13 & 3 & 7 & 16 & 9 & 16 & 5 & 19 & 4 & 715 & 15 & 18 & $1152^{5}$ & 44 \\
\hline Upośledzający & 6 & 5 & 7 & 7 & 2 & 6 & 14 & 17 & 13 & 8 & 15 & 8 & 11 & 0 & 5 & 14 & 8 & 13 & 4 & 15 & 2 & 96 & 11 & 15 & 40 & 35 \\
\hline
\end{tabular}

Rys. 1b. Profil zdolności uczenia się - klasa III gimnazjum (linia ciągła - kobiety, linia przerywana - mężczyźni)

Źródło: E. Filipiak 2009: 63.

Inne efekty uzyskamy stosując dynamiczną procedurę badania, jaką tworzy eksperyment nauczający i metoda mikrogenetyczna. Tworzą one możliwość diagnozowania strefy najbliższego rozwoju dziecka (SNR). Diagnozowanie strefy najbliższego rozwoju to diagnozowanie potencjału uczenia i podatności dziecka na nauczanie, jego reakcji na instrukcję, transferu rozwojowego zadania. Rejestrujemy zdolność ucznia do korzystania $\mathrm{z}$ instrukcji, doświadczenia dziecka w sytuacji uczenia. Poprzez interakcje formatywne z dorosłym, który ukierunkowuje aktywność dziecka związaną z rozwiązywaniem problemów tkwiących w zadaniu, dziecko doświadcza upośrednianego uczenia się i przyswaja sobie strategie strukturujące i samoregulacyjne. Procedury tworzenia mapy najbliższego rozwoju dla myślenia teoretycznego dzieci w wieku wczesnoszkolnym (oszacowanie gotowości poznawczej) i próbę wykreślenia repertuaru skutecznych interwencji w stosowanych zadaniach rozwojowych rejestrowano w przeprowadzonym eksperymencie nauczającym w projekcie ACK (Filipiak, Lemańska 2015a,b). Rejestrowano wspomagany i niewspomagany obszar działalności dzieci. Badania ukierunkowane na szacowanie granic zdolności dziecka do wykonania zadania na strefę najbliższego rozwoju ujawniły całkiem odmienny obraz ich kompetencji. W badaniach uczestniczyły dzieci w wieku 6-10 lat, w tym dzieci z trudnościami w uczeniu. Dzieci w tym samym wieku różniły się znacząco w strategiach rozwiązywania zadań. Wszystkie dzieci ujawniły (zróżnicowaną) „gotowość” do kompetentnego działania. Badawcza, społeczna sytuacja uczenia się ujawniła, jak różna musi być „długość tyczki pomocniczki”, ilość i typ wskazówek potrzebnych konkretnemu dziecku do rozwiązania zadania. To pozwoliło zaobserwować transfer uczenia się i próbę oszacowania szerokości strefy najbliższego rozwoju: oszacowania, jak szybko dzieci się uczą, jak daleko z pomocą dorosłego potrafią dojść w rozwiązywaniu zróżnicowanych pod względem trudności zadań, w jaki sposób dokonuje się transfer nowych umiejętności i przejście od zadania 1. do zadania 2., jaka jest ich podatność na do- 
świadczania uczenia się z dorosłym, czy są podatne na wskazówki i instrukcje. Interwencje formatywne osób towarzyszących dziecku w badaniu/uczeniu się pozwoliły dzieciom na dochodzenie do granic rozumienia. Nauczyciel, podejmując działania wspierające rozumienie, nie mówił dziecku, co ma robić, ale współkonstruował zadanie, rezygnował stopniowo z kontroli i przekazywał dziecku (dzieciom). Sesje treningowe w eksperymencie ukierunkowane były na wspieranie rozumienia, samokontrolę, internalizację własnych procesów poznawczych (Filipiak, Lemańska-Lewandowska 2015a).

Dynamiczne szacowanie SNR pozwala wykreślić profile uczenia się (są one odmienne od tych, jakie uzyskano stosując test SOI-LA (por. rys. 1a i 1 b). Takie próby podjęła między innymi Brown i Ferrara w swoim projekcie. Na podstawie sesji treningowych i obserwacji dzieci w sytuacji uczenia się wyodrębniono dzieci o odmiennych profilach uczenia się: (1) dzieci wolno uczące się, które miały ograniczony transfer, o niskim IQ (powolne); (2) dzieci szybko uczące się, u których odnotowano szeroki transfer, wysokie IQ (szybkie); (3) dzieci szybko uczące się, które dokonywały ograniczonego kontekstem transferu; (4) dzieci wolno uczące się, które dokonywały szerokiego transferu (refleksyjne) oraz (5) dzieci szybko uczące się, które dokonywały szerokiego transferu, o niskim IQ (Brown, Ferrara 1994: 240-241). Te profile są ukryte, jeśli badacz jest zainteresowany diagnozą SAR, której celem jest aktualizacja posiadanego doświadczenia przez dziecko i zakończone już cykle rozwojowe oraz niewspomagany poziom wykonania zadania (por. Brown, Ferrara 1994). Miary dynamiczne potencjału możliwości uczenia (SNR) ujawniają różnice indywidualne dzieci, ich zdolność do korzystania z wskazówek i transfer efektów doświadczenia z sytuacji uczenia. Dynamiczne szacowanie SNR dostarcza wartościowej informacji w zakresie kompetencji rozwoju dziecka, i ma charakter narzędzia interwencyjnego.

\section{Konkluzja}

Badania zainspirowane eksperymentalną metodą Wygotskiego-Elkonina-Davidowa umożliwiającą eksplorowanie i poszerzanie potencjalnych możliwości uczenia się dzieci są kontynuowane w Laboratorium Zmiany Edukacyjnej - Centrum Badań nad Uczeniem się i Rozwojem (por. Filipiak 2018). Prace badawcze w Laboratorium ukierunkowane są zarówno na konstruowanie, testowanie zadań rozwojowych, narzędzi diagnostycznych o znaczeniu interwencyjnym, jak również obejmują działania ukierunkowane na przygotowanie nauczycieli do wdrażania nauczania rozwijającego. Rejestrowane są zarówno sesje treningowe z dziećmi w sytuacji uczenia się, w których analizowana jest wrażliwość dzieci na interwencje formatywne, współzmienność zachowania partnerów interakcji, jak również sesje badawcze z zaangażowanym udziałem „nauczycieli interwencjonistów”. Eksperyment formatywny realizowany z udziałem nauczycieli i studentów pokazał, jak ważna dla organizacji warunków nauczania rozwijającego i środowiska sprzyjającego budowaniu układu uczenia się jest zmiana „teorii dziecka”, postrzegania jego możliwości w sytuacji uczenia, uznanie, że jest ono zdolne do myślenia, rozumowania. Ważnym ob- 
szarem badań w laboratorium są badania nad interwencjami formatywnymi, wskazówkami udzielanymi dziecku umożliwiającymi osiąganie rozumienia.

\section{Literatura}

Bodrowa E., Leong D.J. (2007), Tools of the Mind. The Vygotskian Approach to Early Childhood Education. New York, Pearson.

Brown A.I., Ferrara R.A. (1994), Poznawanie stref najbliższego rozwoju. W: A. Brzezińska, G. Lutomski (red.), Dziecko w świecie ludzi i przedmiotów. Poznań, Zysk i S-ka.

Brzezińska A. (2000), Społeczna psychologia rozwoju. Warszawa, Wyd. Naukowe Scholar.

Brzezińska A.I. (2015), Obserwacja dziecka w sytuacji zadaniowej-konstruowanie skali SOD-SZ. W: E. Filipiak (red.), Nauczanie rozwijające wedtug Lwa S. Wygotskiego. Od teorii do zmiany w praktyce. Bydgoszcz, ArtStudio.

Filipiak E. (2009), Z Wygotskim i Brunerem w tle: Rozwój zdolności uczenia się uczniów szkoły podstawowej i gimnazjum. Niepublikowany raport z badań, Katedra Dydaktyki i Studiów nad Kulturą Edukacji, Instytut Pedagogiki UKW, Bydgoszcz.

Filipiak E. (2012), Produkty kultury uczenia się uczniów szkoły podstawowej i gimnazjum. „Forum Oświatowe", 1(46).

Filipiak E. (2015a), Zdolności wytwarzania konwergencyjnego i dywergencyjnego uczniów szkoły podstawowej i gimnazjum. „Kwartalnik Pedagogiczny”, 4(238).

Filipiak E. (2015b), Zdolności uczenia się uczniów kończacych I i II etap edukacji. „Edukacja”, 1.

Filipiak E. (2015c), Budowanie rusztowania dla myślenia i uczenia się dzieci w perspektywie spoteczno-kulturowej teorii Lwa S. Wygotskiego. W: E. Filipiak (red.), Nauczanie rozwijajace we wczesnej edukacji wedlug Lwa S. Wygotskiego. Od teorii do zmiany w praktyce. Bydgoszcz, ArtStudio.

Filipiak E. (2018), Cultural-historical theory by Lev S. Vygotsy (CHAT): strategies of studies on children's learning and development. From theory to change in practice.

Filipiak E. (red.) (2015), Nauczanie rozwijajace we wczesnej edukacji wedtug Lwa S. Wygotskiego. Od teorii do zmiany w praktyce. Bydgoszcz, ArtStudio.

Filipiak E., Lemańska-Lewandowska E. (2015 a), Model nauczania rozwijającego wedtug Lwa S. Wygotskiego we wczesnej edukacji. Gotowość studentów i nauczycieli. Możliwości aplikacji. Raport tematyczny z badań ACK. Bydgoszcz, ArtStudio.

Filipiak E., Lemańska-Lewandowska E. (2015 b), Możliwości rozwijania myślenia i uczenia się dzieci poprzez stawianie zadań rozwojowych. W: E. Filipiak (red.), Nauczanie rozwijajace wedtug Lwa S. Wygotskiego we wczesnej edukacji dziecka. Od teorii do zmiany w praktyce. Bydgoszcz, ArtStudio.

Kin-Wiśniewska M. (2009), „Miłość jest jak wiatrak”- czyli o poznawczej naturze metafor dziecięcych. Łódź, Wyd. Uniwersytetu Łódzkiego.

Klus-Stańska D. (2002), Konstruowanie wiedzy w szkole. Olsztyn, Wyd. UWM.

Meeker M., Meeker R., and Roid G.H. (1985), Structure of Intellect Learning Abilities Test (SOI$L A)$. WPS.

Stachowski R. (2002), Lew S. Vygotsky - prekursor psychologii o dwóch obliczach. W: A. Brzezińska, M. Marchow (red.), Lew S. Vygotsky. Wybrane prace psychologiczne II. Dzieciństwo i dorastanie. Poznań, Zysk i S-ka. 
Shotter J. (1994). Psychologia Wygotskiego - wspólna aktywność w strefie rozwoju. W: A. Brzezińska, G. Lutomski (red.), Dziecko w świecie ludzi i przedmiotów. Poznań, Zysk i S-ka.

Smykowski B. (2000), Podejście rozwojowe do badania złożonych form zachowań. W: Nieobecne dyskursy. Cz. 6. A.I. Brzezińska (red.). Wygotski i z Wygotskim w tle. Toruń, Wyd. UMK.

Smykowski B. (2017), Eksperymentalna metoda podwójnej stymulacji w diagnozowaniu gotowości dzieci do uczenia się pod kierunkiem. „Psychologia Wychowawcza”, 11.

Stemplewska-Żakowicz K. (2004), O rzeczach widywanych na obrazkach i opowiadanych o nich historiach. TAT jako metoda diagnostyczna. Warszawa, Academica.

Wood D. (2006), Jak dzieci ucza się i myślą. Społeczne konteksty rozwoju poznawczego. Kraków, Wyd. UJ.

Wygotski L.S. (1971), Wybrane prace psychologiczne. Warszawa, PWN.

Wygotski L.S. (1989), Myślenie i mowa. Warszawa, PWN.

Zak A. (1989), Rozwój myślenia teoretycznego u dzieci w młodszym wieku szkolnym. Warszawa, WSiP.

Zuckerman G.A. (2007), Child-adult interaction that creates a zone of proximal development. "Journal of Russian and East European Psychology", 45(3). 